\title{
PEMODELAN GERAK PENDULUM VERTIKAL PADA KONVERTER ENERGI GELOMBANG BERINERSIA TAMBAHAN SAAT RESONANSI
}

\author{
Ardi Noerpamoengkas ${ }^{1}$, Miftahul Ulum ${ }^{2}$ \\ 1,2 Jurusan Teknik Mesin, Fakultas Teknologi Industri \\ Institut Teknologi Adhi Tama Surabaya, Jl. Arief Rahman Hakim No.100 Surabaya, 60117 \\ Email: ardi@itats.ac.id ${ }^{1}$
}

\begin{abstract}
The huge sea wave energy potency can be used by applying wave energy converter. A kind of this model is vertical pendulum mechanism. Ordinary vertical pendulum modeling makes pendulum mass influence to pendulum movement insignificantly. Developed model with power transmission have not accommodated resonance condition. Therefore, this research models and analyzes pendulum responses on wave energy converter with additional inertia at resonance. Pendulum response amplitudes relative to vertical gravity direction are bigger in longer time and saturated to pontoon movement amplitude at steady condition, whereas response amplitudes relative to pontoon are smaller. These phenomena are not happened at the other conditions.
\end{abstract}

Keywords: wave energy converter, vertical pendulum, additional inertia, resonance.

\begin{abstract}
ABSTRAK
Potensi energi gelombang laut yang besar dapat dimanfaatkan dengan menerapkan konverter energi gelombang. Salah satu model konverter yang sedang dikembangkan model pendulum vertikal. Pemodelan pendulum vertikal yang sederhana menyebabkan pengaruh massa tidak signifikan terhadap respon gerak pendulum. Demikian juga dengan model dengan penambahan transmisi daya tidak mengakomodir kondisi resonansi. Oleh karena itu, penelitian ini memodelkan dan menganalisis respon gerak pendulum pada konverter energi gelombang dengan inersia tambahan saat resonansi. Amplitudo respon pendulum relatif terhadap arah vertikal gravitasi semakin lama semakin membesar hingga dibatasi nilai amplitudo pergerakan ponton pada kondisi tunak, sedangkan respon relatif terhadap ponton semakin mengecil. Fenomena ini tidak terjadi pada kondisi di luar resonansi.
\end{abstract}

Kata kunci: pendulum vertikal, konverter energi gelombang, inersia tambahan, resonansi

\section{PENDAHULUAN}

Indonesia memiliki potensi energi kelautan yang besar, salah satunya potensi energi gelombang laut. Gerak naik-turun pada arah transversal gelombang ini dapat menggerakkan suatu mekanisme konversi energi tertentu. Mekanisme ini akan mengubah gerak gelombang tersebut menjadi gerak rotasi yang nantinya dapat digunakan untuk memutar generator. Model pendulum yang ditempatkan di atas suatu media terapung dapat menjadi mekanisme tersebut.

Salah satu model pendulum yang diteliti adalah pendulum vertikal. Pendulum jenis ini dipilih karena memiliki respon gerakan yang lebih mudah dimodelkan daripada pendulum horizontal [1-4]. Tinjauan respon pendulum vertikal dalam kondisi mendekati resonansi pernah dilakukan pada model pendulum yang masih sangat sederhana dengan hanya pendulum vertikal yang bergerak relatif terhadap ponton [5]. Model ini memiliki frekuensi natural yang hanya dipengaruhi oleh panjang lengan pendulum. Perlu adanya penelitian lebih lanjut agar parameter sistem pendulum vertikal lain, seperti massa pendulum, dapat turut mempengaruhi frekuensi natural pendulum vertikal.

Oleh karena itu, model pendulum vertikal diberi inersia tambahan dalam penelitian ini. Massa pendulum turut mempengaruhi frekuensi natural pada kondisi ini. Semua nilai parameter sistem dan eksitasi ditentukan sedemikian sehingga frekuensi eksitasi sama dengan frekuensi natural sistem. Penelitian ini dapat memberikan respon gerak pendulum domain waktu pada 
kondisi yang lebih riil dengan melibatkan faktor massa pendulum dan inersia tambahan pada model matematis, dan juga dapat mengetahui respon tersebut dalam kondisi resonansi apakah nilainya menurun seperti pada kondisi tanpa diberi inersia tambahan [5]. Inersia tambahan ini nantinya dapat mewakili roda gigi, flywheel, generator armature atau beban inersia lain pada kondisi riil. Respon pendulum domain waktu ini akan digunakan untuk menjadi input gerakan rotasi pada transmisi daya hingga generator.

\section{TINJAUAN PUSTAKA}

Konverter energi gelombang laut memiliki berbagai macam mekanisme, salah satunya mekanisme pendulum. Model pendulum horizontal/datar diperkenalkan pertama kali oleh Zamrisyaf SY, dimodelkan pertama kali oleh Ardi et al [1], dan diuji secara eksperimen menggunakan simulator gelombang oleh Ario et al [2]. Selanjutnya dikembangkan pendulum datar tunggal ditempatkan pada ponton dan diberi transmisi roda gigi [3,4], dan pendulum datar tiga [6,7]. Pendulum kemudian dikembangkan dengan membuatnya menyudut terhadap arah normal ponton sehingga berbentuk konis [8-10]. Baik model pendulum datar maupun konis, tunggal maupun ganda, memiliki konsep yang hampir sama dengan menerapkan analogi inersia pendulum pada berbagai model tersebut. Model pendulum seperti ini menghasikan gerak pendulum yang cenderung acak, dan inersia pendulum mempertahankan putaran tetap kontinyu.

Model pendulum vertikal hanya menghasilkan gerak pendulum yang berayun pada satu bidang sehingga pergerakannya dapat diprediksi dan tidak acak jika dibandingkan model pendulum datar. Model pendulum vertikal sederhana ditempatkan di atas ponton yang bergerak miring osilasi [5,11]. Pengembangan selanjutnya dilakukan dengan menambahkan transmisi roda gigi $[12,13]$, dan dikombinasikan dengan lengan angguk [14]. Daya bangkitan akan semakin besar jika lengan pendulum semakin pendek, massa pendulum semakin besar. Respon pendulum vertikal sederhana menurun pada kondisi amplitudo eksitasi tinggi dan frekuensi mendekati frekuensi natural [5].

Pemodelan pendulum vertikal [5] dilakukan sederhana sehingga diperoleh persamaan model matematis sebagai berikut.

$$
B \cdot \dot{\alpha}=m \cdot L^{2} \cdot \ddot{\beta}+B \cdot \dot{\beta}+m \cdot g \cdot L \cdot \beta
$$

Di mana $\mathrm{m}$ adalah massa pendulum, $\mathrm{L}$ panjang pendulum, g konstanta gravitasi, B redaman pada pangkal pendulum, $\alpha$ sudut kemiringan ponton, dan $\beta$ sudut pendulum vertikal terhadap equilibrium. Adapun $\omega_{\mathrm{n}}$, frekuensi natural pendulum vertikal sebagai berikut. $\omega_{\mathrm{n}}=\sqrt{g / L}$

Persamaan 2 menunjukkan frekuensi natural dari model pendulum vertikal yang sederhana tidak dapat mengakomodir pengaruh massa pendulum terhadap frekuensi natural. Oleh karena itu, penelitian ini mengembangkan model sehingga massa pendulum dan inersia tambahan dapat mempengaruhi frekuensi natural gerak pendulum.

\section{METODE}

Pendulum vertikal dan ponton digambarkan pada model konfigurasi Gambar 1. sebagaimana penelitian sebelumnya [5,11]. Kedua sisi ponton diberikan eksitasi harmonik. Pemodelan menggunakan metode persamaan variabel keadaan [15].

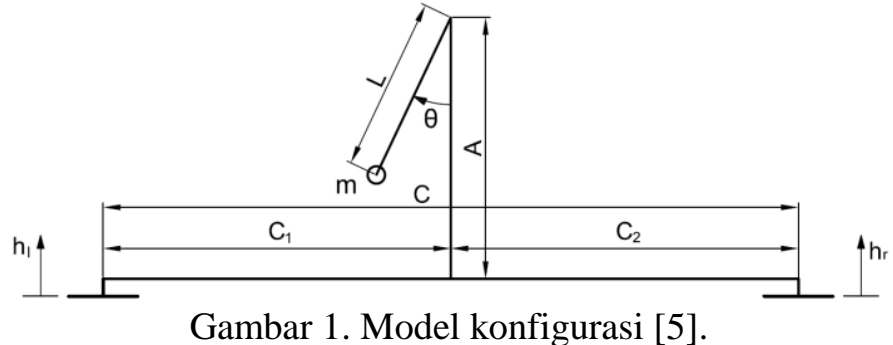




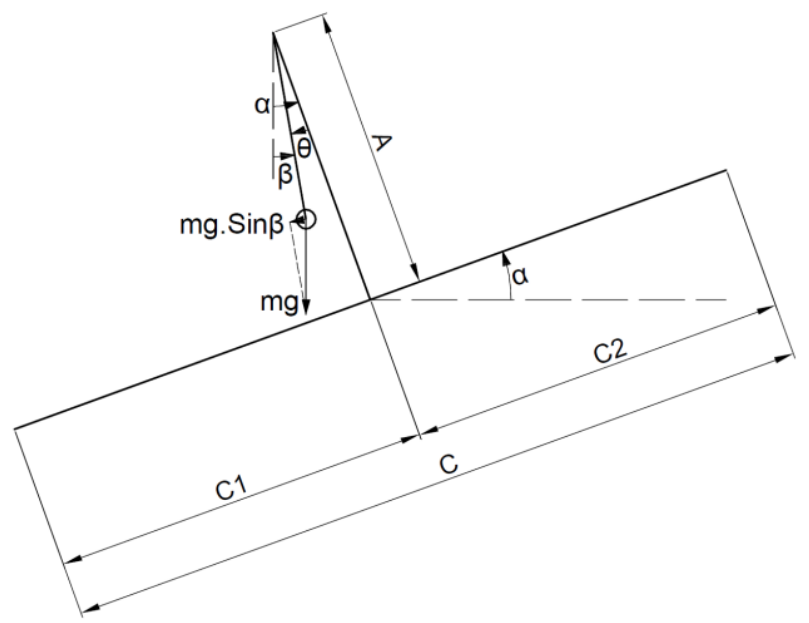

Gambar 2. Hubungan sudut $\alpha, \beta$, dan $\theta[5]$.

Identitas model konfigurasi di atas antara lain $h_{1}$ sebagai eksitasi ponton sisi kiri, $h_{r}$ yang sisi kanan, dan $\theta$ sudut simpang pendulum-tiang pendulum. Eksitasi pada ponton dirumuskan sebagai berikut.

$$
\begin{aligned}
& h_{l}=H_{l} \cdot \operatorname{Sin}\left(\omega_{l} \cdot t-\varphi\right) \\
& h_{r}=H_{r} \cdot \operatorname{Sin}\left(\omega_{r} \cdot t\right) \\
& \alpha=\left(h_{r}-h_{l}\right) / C
\end{aligned}
$$

Hubungan antar sudut respon yang terkait pendulum dapat dilihat pada Gambar 2, di mana $\alpha$ adalah sudut simpang ponton terhadap garis semu horizontal atau/sama dengan sudut simpang tiang pendulum terhadap garis semu vertikal, $\beta$ adalah sudut simpang pendulum terhadap garis semu vertikal/posisi equilibrium-nya, dan $\theta$ adalah sudut simpang pendulum relatif terhadap tiang penyangga pendulum. Selain itu, juga dapat dirumuskan sebagai berikut. $\alpha=\beta+\theta$

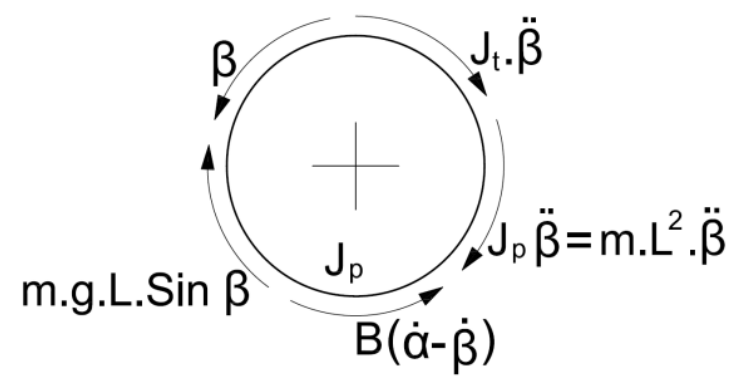

Gambar 3. Free body diagram gerak pendulum vertikal.

Adanya penambahan inersia pada sistem membuat free body diagram gerak pendulum seperti pada Gambar 3. Persamaan variabel keadaan untuk free body diagram di atas sebagai berikut.

$$
\begin{aligned}
& \omega_{\beta}=\dot{\beta} \\
& \dot{\omega}_{\beta}=\frac{1}{J_{t}+m \cdot L^{2}}[-B \cdot \dot{\beta}-m \cdot g \cdot L \cdot \beta+B \cdot \dot{\alpha}]
\end{aligned}
$$

Frekuensi natural pendulum vertikal menjadi berikut.

$\omega_{\mathrm{n}}=\sqrt{\frac{m \cdot g \cdot L}{J^{2}+m \cdot L^{2}}}$ 
Selanjutnya persamaan 7 dan 8 akan disolusikan menggunakan komputasi numerik dengan tipe solver ODE4 dan step size 0,001. Nilai-nilai parameter sistem dan eksitasi [16] agar diperoleh kondisi resonansi sebagai berikut.

Tabel 1. Parameter sistem dan eksitasi.

\begin{tabular}{lllll}
\hline No. & Notasi Parameter & Jenis Parameter & Nilai & Satuan \\
\hline 1 & $\mathrm{~g}$ & Konstanta gravitasi & 9,8 & $\mathrm{~m} / \mathrm{s}^{2}$ \\
\hline 2 & $\mathrm{C}_{1}$ & Jarak tengah-sisi kiri ponton & 1 & $\mathrm{~m}$ \\
\hline 3 & $\mathrm{C}_{2}$ & Jarak tengah-sisi kanan ponton & 1 & $\mathrm{~m}$ \\
\hline 4 & $\mathrm{C}$ & Jarak sisi kiri-kanan ponton & 2 & $\mathrm{~m}$ \\
\hline 5 & $\mathrm{~A}$ & Tinggi tiang pendulum & 6 & $\mathrm{~m}$ \\
\hline 6 & $\mathrm{~L}$ & Panjang lengan pendulum & 3 & $\mathrm{~m}$ \\
\hline 7 & $\mathrm{~m}$ & Massa pendulum & 5,5 & $\mathrm{~kg}$ \\
\hline 8 & $\mathrm{~B}$ & Redaman poros pendulum-bantalan & 0,5 & $\mathrm{~N} \cdot \mathrm{m} . \mathrm{s} / \mathrm{rad}$ \\
\hline 9 & $\mathrm{~J}_{\mathrm{t}}$ & Beban inersia tambahan & 360,5 & $\mathrm{~kg} \cdot \mathrm{m} 2$ \\
\hline 10 & $\mathrm{H}_{\mathrm{exc}}=\mathrm{H}_{1}=\mathrm{H}_{\mathrm{r}}$ & Tinggi / amplitudo gelombang & 1,5 & $\mathrm{~m}$ \\
\hline 11 & $\tau_{\mathrm{exc}}=\tau_{1}=\tau_{\mathrm{r}}$ & Periode gelombang & 10 & $\mathrm{detik}$ \\
\hline 12 & $\omega_{\mathrm{exc}}=\omega_{1}=\omega_{\mathrm{r}}$ & Frekuensi gelombang & $\pi / 5$ & $\mathrm{rad} / \mathrm{s}$ \\
\hline 13 & $\lambda_{\mathrm{exc}}=\lambda_{1}=\lambda_{\mathrm{r}}$ & Panjang gelombang & 600 & $\mathrm{~m}$ \\
\hline 14 & $\varphi$ & Beda fase eksitasi sisi kiri-kanan ponton & $\pi / 150$ & $\mathrm{rad}$ \\
\hline
\end{tabular}

\section{HASIL DAN PEMBAHASAN}

Simulasi pemodelan menghasilkan grafik respon perpindahan, kecepatan, dan percepatan sudut pendulum vertikal. Grafik dalam domain waktu dengan rentang yang mencakup kondisi transien dan tunak pendulum vertikal, atau hingga detik ke-10.000.

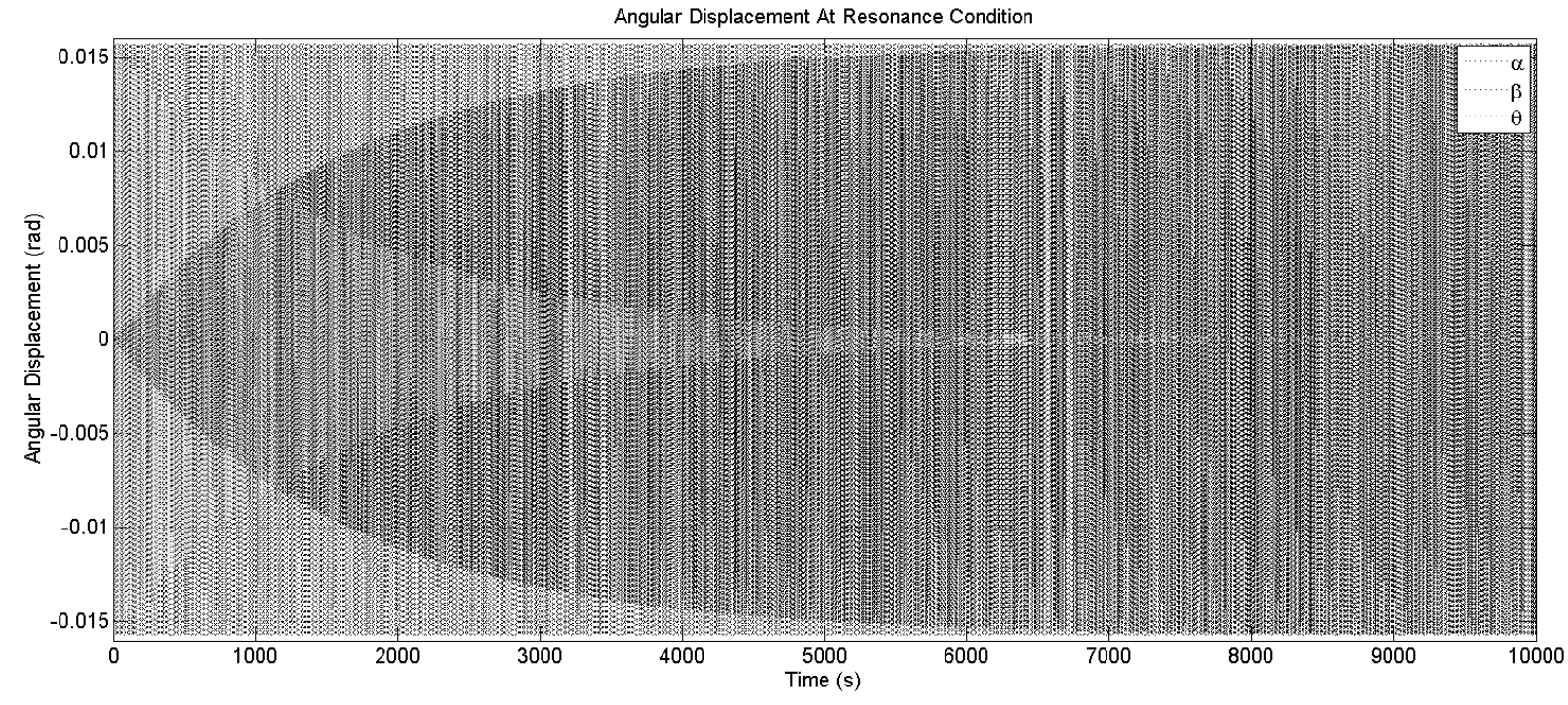

Gambar 4. Respon angular displacement saat resonansi. 


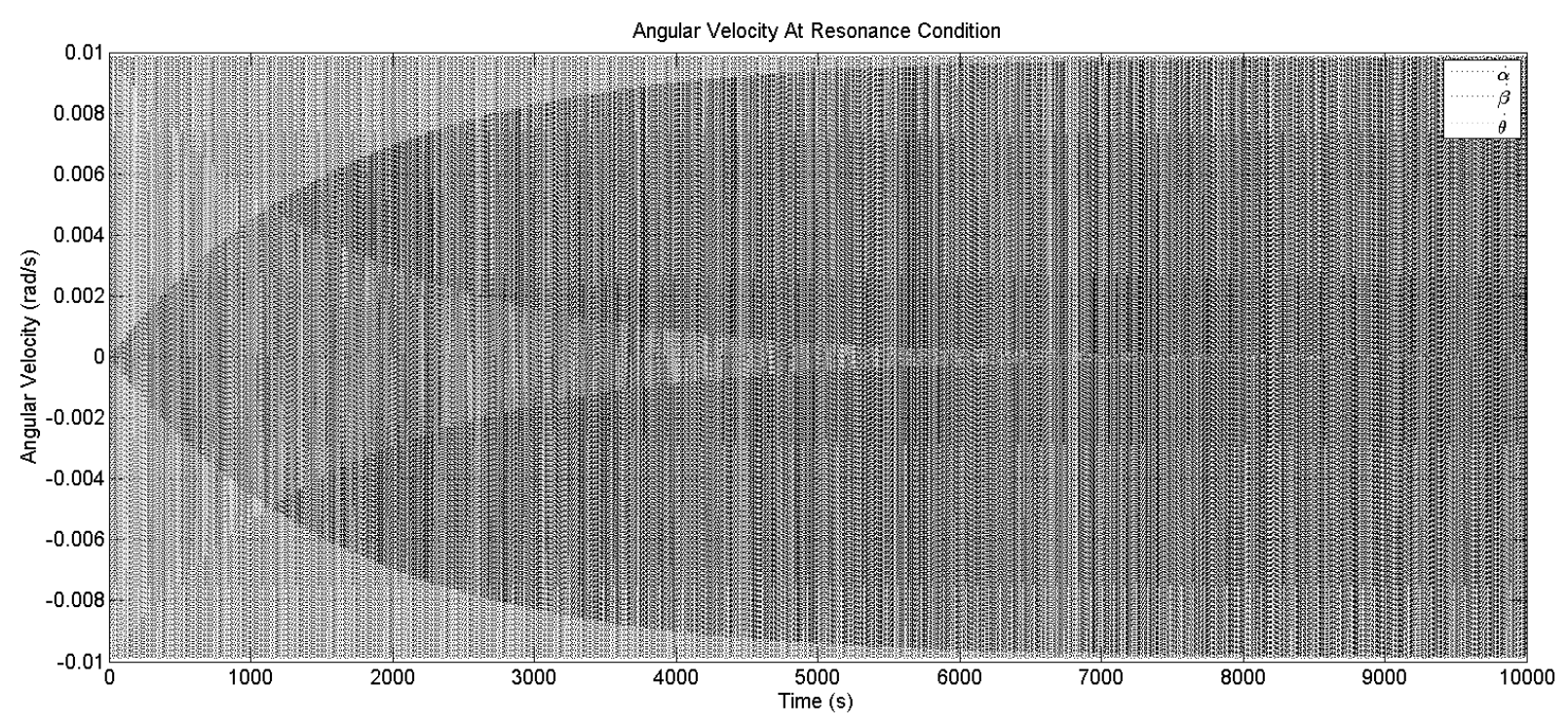

Gambar 5. Respon angular velocity saat resonansi.

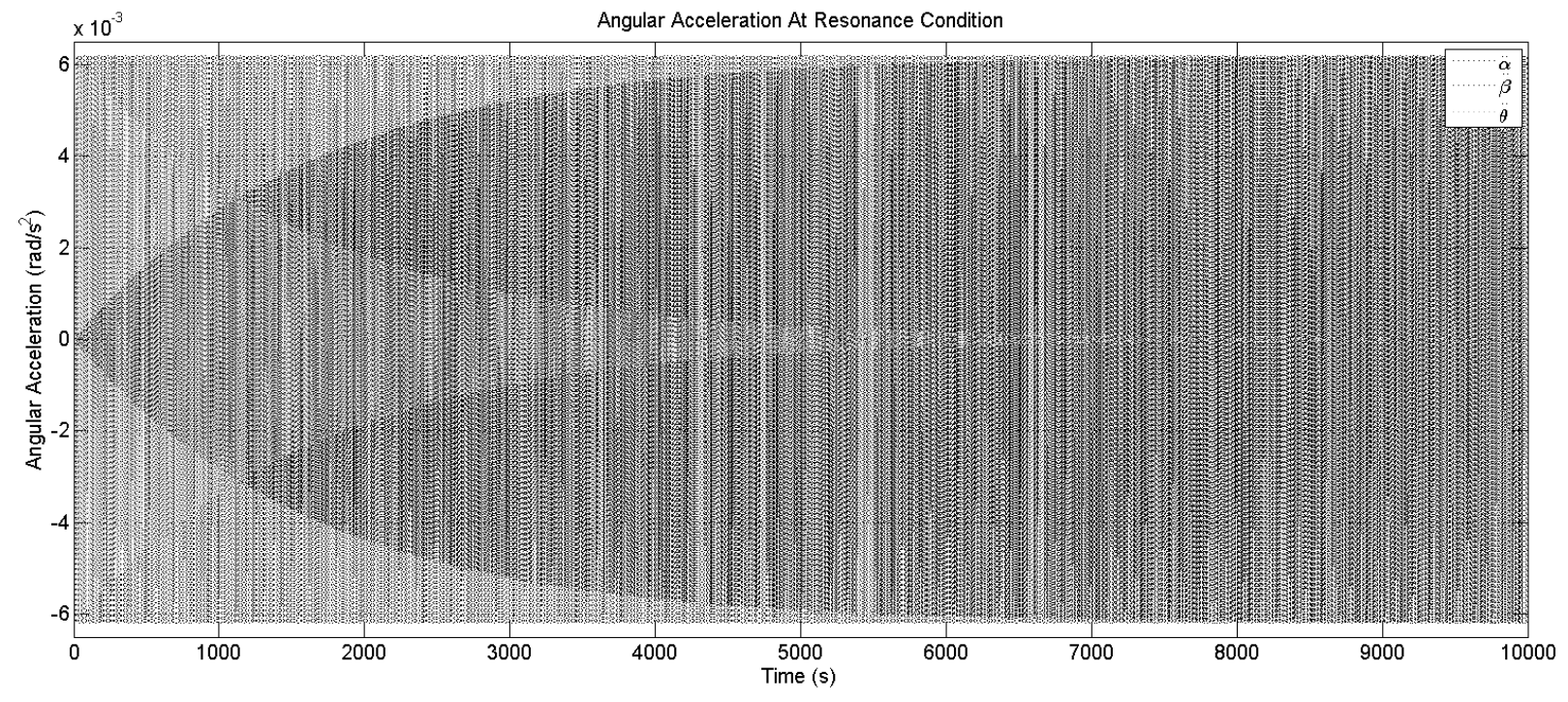

Gambar 6. Respon angular acceleration saat resonansi.

Warna hitam pada grafik gambar 4 menunjukkan sudut $\alpha$, warna biru untuk sudut $\beta$, dan warna hijau untuk sudut $\theta$. Warna hitam pada grafik Gambar 5 menunjukkan turunan pertama sudut $\alpha$ terhadap waktu, warna biru untuk turunan pertama sudut $\beta$ terhadap waktu, dan warna hijau untuk turunan pertama sudut $\theta$ terhadap waktu. Warna hitam pada grafik Gambar 6 menunjukkan turunan kedua sudut $\alpha$ terhadap waktu, warna biru untuk turunan kedua sudut $\beta$ terhadap waktu, dan warna hijau untuk turunan kedua sudut $\theta$ terhadap waktu. Respon displacement sudut, kecepatan sudut, dan percepatan sudut pendulum disebut sebagai respon pendulum untuk penyerhanaan. Ketiga grafik ini digunakan untuk mengetahui perbandingan respon pendulum vertikal relatif terhadap posisi equilibrium-nya (sudut $\beta$ ), relatif terhadap tiang pendulum (sudut $\theta$ ), dan sudut simpang tiang pendulum terhadap garis semu vertikal (sudut $\alpha$ ) sehingga diketahui fenomena yang terjadi hingga kondisi tunak. Kondisi tunak terjadi saat respon pendulum tidak mengalami perubahan amplitudo yang signifikan seiring berjalannya waktu.

Ketiga grafik respon pendulum di atas menunjukkan bahwa terjadi kenaikan amplitudo respon pendulum vertikal terhadap arah vertikal/posisi equilibrium (sudut $\beta$ ) yang diiringi penurunan amplitudo respon pendulum vertikal relatif terhadap tiang penyangganya (sudut $\theta$ ). 
Peningkatan respon sudut $\beta$ menunjukkan efek resonansi yang menyebabkan peningkatan amplitudo pada sudut pendulum $\beta$, bukan $\theta$, karena kondisi kesetimbangan pendulum memang berada di arah semu vertikal searah gravitasi (datum sudut $\beta$ ), bukan tiang penyangganya pada ponton (datum sudut $\theta$ ).

Ketiga grafik juga menunjukkan kenaikan amplitudo respon sudut $\beta$ ini hanya terbatas pada amplitudo dari pergerakan ponton (sudut $\alpha$ ) saat kondisi tunak. Hal ini dikarenakan gerak miring ponton osilasi memaksa pendulum vertikal bergerak mengikutinya sehingga amplitudo pergerakan pendulum vertikal tidak melebihi amplitudo pergerakan ponton. Kondisi ini menyebabkan pendulum vertikal tidak dapat berputar kontinyu kecuali jika ada torsi pemutarnya yang juga kontinyu atau tidak berosilasi seperti pergerakan miring ponton.

Amplitudo respon angular displacement pendulum sudut $\theta$ antara kondisi saat resonansi dan kondisi nilai inersia tambahan lebih rendah (nilai frekuensi natural lebih tinggi) dapat dilihat pada grafik Gambar 7. Sedangkan kondisi saat resonansi dan saat nilai inersia tambahan lebih tinggi (nilai frekuensi natural lebih rendah) dapat dilihat pada grafik Gambar 8. Nilai inersia tambahan untuk kondisi resonansi sebesar $361 \mathrm{~kg} \cdot \mathrm{m}^{2}$. Kedua grafik menunjukkan perbedaan kondisi saat resonansi dibandingkan dua kondisi yang lain. Kondisi saat resonansi menghasilkan amplitudo respon sudut $\theta$ yang semakin lama semakin mengecil, tidak sama seperti kondisi yang lain. Amplitudo sudut $\beta$ pun akan menunjukkan hasil yang berkebalikan karena amplitudo sudut $\alpha$ sama. Tentu fenomena ini disebabkan oleh resonansi yang telah dibahas pada paragraf sebelumnya. Penelitian lebih lanjut diperlukan untuk mengetahui respon pendulum vertikal pada sekitar kondisi resonansi tersebut.

Pemodelan pendulum vertikal ini valid terhadap pemodelan pada penelitian sebelumnya [5] karena menunjukkan tren hasil yang sama pada daerah sekitar kondisi resonansi. Pada penelitian sebelumnya, hasil respon pendulum vertikal relatif terhadap tiangnya (sudut $\theta$ dan turunan pertamakeduanya terhadap waktu) paling rendah terjadi pada kondisi resonansi. Sedangkan, respon tersebut meningkat pada kondisi frekuensi eksitasi yang lebih besar atau lebih kecil dibandingkan frekuensi natural. Frekuensi natural diubah dengan mengubah nilai inersia tambahan pada penelitian ini.

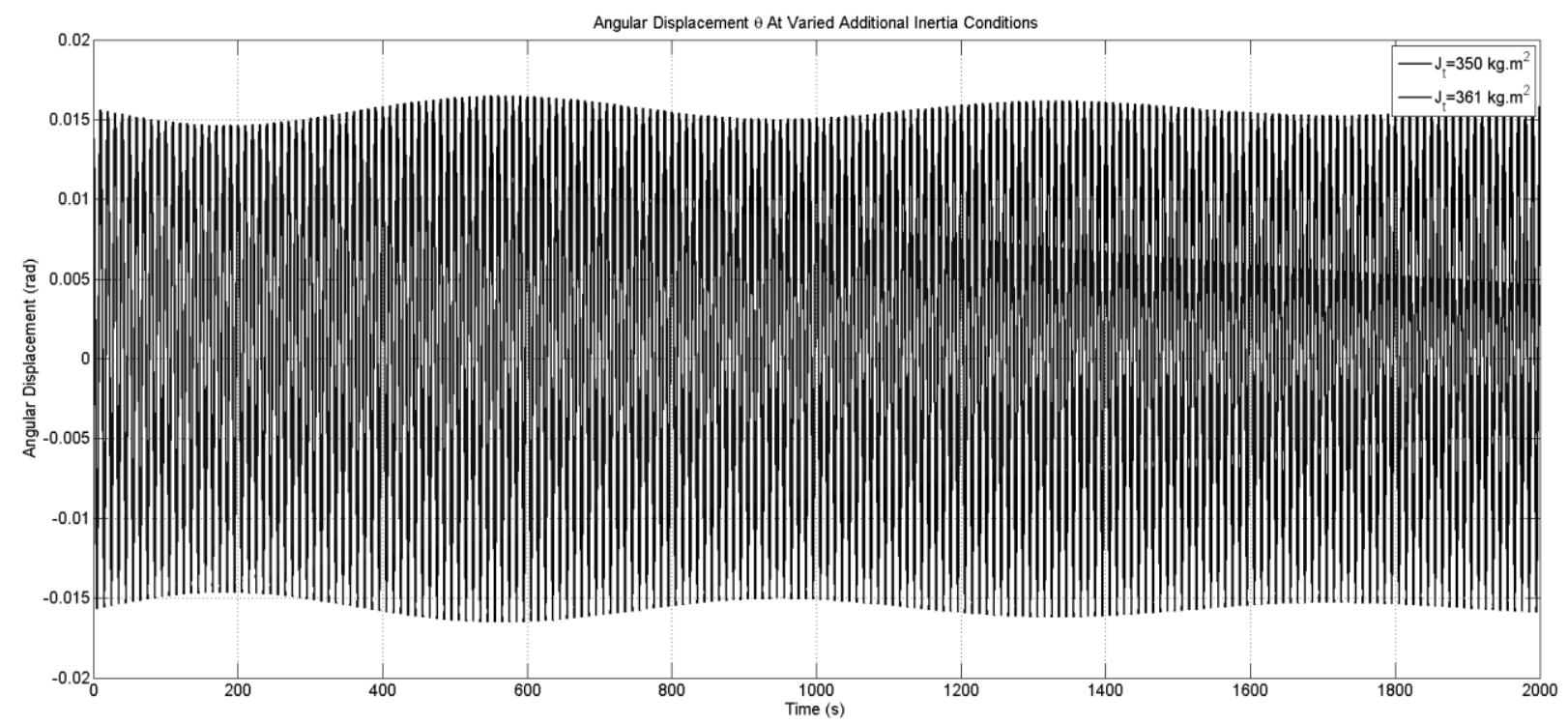

Gambar 7. Respon sudut $\theta$ untuk nilai $\mathrm{J}_{\mathrm{t}} 350 \mathrm{~kg} \cdot \mathrm{m}^{2}$ dan $361 \mathrm{~kg} \cdot \mathrm{m}^{2}$. 


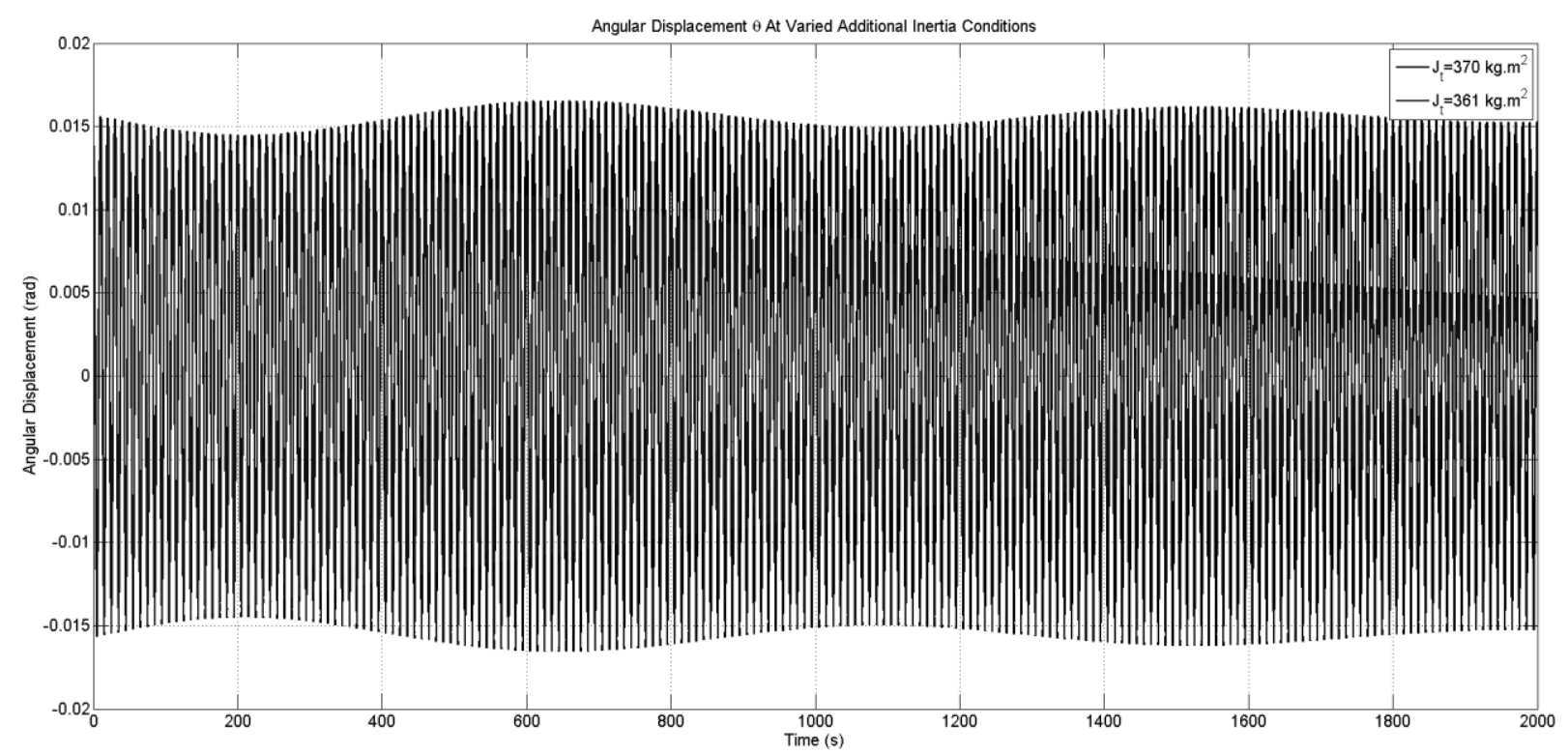

Gambar 8. Respon sudut $\theta$ untuk nilai $\mathrm{J}_{\mathrm{t}} 370 \mathrm{~kg} \cdot \mathrm{m}^{2}$ dan $361 \mathrm{~kg} \cdot \mathrm{m}^{2}$.

Konversi energi gelombang akan memanfaatkan respon sudut $\theta$. Transmisi daya atau generator akan terpasang pada ponton sehingga gerak relatif pendulum terhadap ponton yang dipakai. Kondisi resonansi justru menghasilkan perubahan amplitudo respon sudut $\theta$ terhadap waktu yang semakin kecil sehingga tidak cocok untuk konversi energi gelombang.

\section{KESIMPULAN}

Amplitudo respon pendulum vertikal relatif terhadap arah vertikal gravitasi/posisi equilibrium-nya akan semakin besar seiring berjalannya waktu pada kondisi resonansi. Nilai amplitudonya mencapai maksimum saat kondisi tunak, dan tidak melebihi amplitudo pergerakan miring ponton. Sebaliknya, amplitudo respon gerak pendulum relatif terhadap tiang penyangganya pada ponton akan semakin kecil seiring berjalannya waktu. Tren perubahan amplitudo respon gerak pendulum ini tidak terjadi pada kondisi di luar resonansi.

\section{DAFTAR PUSTAKA}

[1]. Ardi Noerpamoengkas, Harus Laksana Guntur, Zamrisyaf SY. 2013. Modeling Flat Pendulum and Simulating Its Validation at The Pendulum - Flat Pontoon Model Sea Wave Electric Generator Application. Institut Teknologi Adhi Tama Surabaya, Jurnal IPTEK, Vol 17 No 1. Mei 2013, ISSN : 1411-7010.

[2]. Ario Pratama. 2012. Studi Eksperimental Pengaruh Panjang Batang dan Massa Pendulum terhadap Energi Listrik yang Dihasilkan pada Simulator Pembangkit Listrik Tenaga Gelombang Laut Sistem Bandul (PLTGL-SB) Ponton Datar. Tugas Akhir, Institut Teknologi Sepuluh Nopember.

[3]. Alviani Hesthi Permata Ningtyas, Wiwiek Hendrowati. 2012. Pemodelan dan Analisa Karakteristik Energi Listrik yang Dihasilkan Mekanisme Pembangkit Listrik Tenaga Gelombang Laut Model Ponton-Single Pendulum. Jurnal Teknik POMITS Vol. 1, No. 2, (2012) ISSN: 2301-9271.

[4]. Putu Risti Nirmalasari, Wiwiek Hendrowati. 2014. Studi Eksperimen dan Analisa Energi Listrik yang Dihasilkan Mekanisme Pembangkit Listrik Tenaga Gelombang Laut dengan Metode Ponton dan Single Pendulum. Jurnal Teknik POMITS Vol. 1, No. 1, (2014) 1-6. 
[5]. Ardi Noerpamoengkas, Miftahul Ulum. 2015. Pemodelan Pengaruh Frekuensi Dan Amplitudo Eksitasi Terhadap Respon Gerak Dan Daya Mekanis Pendulum Vertikal Pada Konverter Energi Gelombang Laut. Prosiding Seminar Nasional Sains dan Teknologi Terapan III, ISBN 978-602-98569-1-0, 201-210.

[6]. Andini Kusumastuti, Yunarko Triwinarno, Harus Laksana Guntur. 2012. Studi Eksperimen Karakteristik Putaran Pendulum Pada Simulator Pembangkit Listrik Tenaga Gelombang Laut Sistem Tiga Pendulum. Jurnal Teknik POMITS Vol. 1, No. 2, (2012) ISSN: 23019271.

[7]. Ibrahim Az. 2015. Rancang Bangun dan Studi Eksperimen Respon Dinamis Model Pembangkit Listrik Tenaga Gelombang Laut Sistem Ponton dengan Tiga Bandul. Tugas Akhir, Institut Teknologi Sepuluh Nopember Surabaya.

[8]. Ni Made Wulan Permata Sari. 2011. Studi Eksperimental Pengaruh Variasi Panjang Lengan Pendulum terhadap Bola Gerak Bandul dan Voltase Bangkitan Generator Pada Simulator Pembangkit Listrik Tenaga Gelombang Laut - Sitem Bandul (PLTGL-SB) Konis. Tugas Akhir, Institut Teknologi Sepuluh Nopember Surabaya.

[9]. Bahairotul Lu'Lu'. 2011. Studi Eksperimental Pengaruh Variasi Sudut Konis terhadap Pola Gerak Pendulum dan Voltase Bangkitan pada Simulator Pembangkit Listrik Tenaga Gelombang Laut Sistem Bandul (PLTGL-SB) Konis. Tugas Akhir, Institut Teknologi Sepuluh Nopember Surabaya.

[10]. Lely Etika Sari. 2011. Studi Eksperimental Pengaruh Variasi Massa Bandul terhadap Pola Gerak Bandul dan Voltase Bangkitan Generator pada Simulator Pembangkit Listrik Tenaga Gelombang Laut-Sistem Bandul Konis. Tugas Akhir, Institut Teknologi Sepuluh Nopember Surabaya.

[11]. Eky Novianarenti, Yerri Susatio, Ridho Hantoro. 2013. Penentuan Parameter Bandul Matematis Untuk Memperoleh Energi Maksimum Dengan Gelombang Dalam Tangki. Jurnal Teknik POMITS Vol. 2, No. 1, (2013) ISSN: 2337-3539, B122-B127.

[12]. Mukhtasor, Rudi Walujo Prastianto, Irfan Syarif Arief, Harus Laksana Guntur, Hadi Setiyawan, Maulidiyah, Zamrisyaf. 2013. Kajian Teknik Rancang Bangun Sistem Transmisi Peningkatan Kinerja Pembangkit Listrik Tenaga Gelombang Laut Dengan Sistem Bandul. Seminar Insentif Riset SINas 2013, 188-197.

[13]. Eva Sofiana. 2015. Rancang Bangun Dan Studi Eksperimen Respon Dinamis Model Pembangkit Listrik Tenaga Gelombang Laut Sistem Ponton Bandul Vertikal. Tugas Akhir, Institut Teknologi Sepuluh Nopember.

[14]. Eky AN, Arief IS, Musriyadi TB. 2013. Penerapan Sistem Pendulum pada Lengan Angguk untuk Pengembangan Energi Gelombang Laut. Jurnal Teknik POMITS Vol. 2, No. 2 (2013), G169-G171.

[15]. Close CM, Frederick DK, Newell JC. 2002. Modeling and Analysis of Dynamic Systems. 3rd ed. Hoboken: John Wiley \& Sons, Inc.

[16]. Zulfikar Adlan Nadzir, Lalu Muhamad Jaelani, Albertus Sulaiman. 2015. Estimasi Tinggi Gelombang Laut Menggunakan Citra Satelit Alos-Palasar Studi Kasus Perairan Pulau Poteran Sumenep. Jurnal Teknik POMITS Vol. XX, No. XX, (2015) ISSN: 2337-3539. 